\title{
Corrigendum: Characterization of Reproductive Dormancy in Male Drosophila melanogaster
}

\author{
Olga I. Kubrak ${ }^{1}$, Lucie Kučerová ${ }^{\dagger}$, Ulrich Theopold ${ }^{2}$, Sören Nylin ${ }^{1}$ and Dick R. Nässel ${ }^{1 \text { * }}$ \\ ${ }^{1}$ Department of Zoology, Stockholm University, Stockholm, Sweden, ${ }^{2}$ Department of Molecular Biosciences, Wenner-Gren \\ Institute, Stockholm University, Stockholm, Sweden
}

Keywords: Drosophila melanogaster, diapause, reproduction, mating, metabolism

\section{A corrigendum on}

Characterization of Reproductive Dormancy in Male Drosophila melanogaster

by Kubrak, O. I., Kučerová, L., Theopold, U., Nylin, S., and Nässel, D. R. (2016). Front. Physiol. 7:572. doi: 10.3389/fphys.2016.00572

\section{OPEN ACCESS}

Edited and reviewed by: Elzbieta M. Pyza,

Jagiellonian University, Poland

${ }^{*}$ Correspondence:

Dick R. Nässel

dnasse/@zoologi.su.se

${ }^{\dagger}$ Present Address:

Lucie Kučerová

Biology Center, Academy of Sciences of the Czech Republic, Institute of

Entomology, Ceske Budejovice,

Czechia

Specialty section:

This article was submitted to Invertebrate Physiology, a section of the journal Frontiers in Physiology

Received: 23 April 2017 Accepted: 01 May 2017 Published: 10 May 2017

Citation:

Kubrak Ol, Kučerová L, Theopold U,

Nylin S and Nässel DR (2017)

Corrigendum: Characterization of Reproductive Dormancy in Male

Drosophila melanogaster. Front. Physiol. 8:314

doi: 10.3389/fphys.2017.00314
It has been noted that several of the citations in this paper are incorrect. These are on pages 4-5 in the sections "Dormancy Affects Reproductive Organs and Spermatogenesis" and "Mating and Fecundity Is Diminished in Dormant Flies." Thus, the correct citations are not in the publication list of the published paper, but are listed below. This error was caused by a problem with introduction of citations from multiple bibliography libraries.

The authors apologize for this error and state that this does not change the scientific conclusions of the article in any way.

(Fricke et al., 2014) should be replaced by (Barreau et al., 2008). (Apger-McGlaughon and Wolner, 2013) should be replaced by (Maines and Wasserman, 1999).

(Gioti et al., 2012) should be replaced by (Krysan, 1990).

(Swanson, 2003) should be replaced by (Krysan and Higbee, 1990).

(Chapman et al., 2003) should be replaced by (Sadakiyo and Ishihara, 2012).

\section{REFERENCES}

Barreau, C., Benson, E., Gudmannsdottir, E., Newton, F., and White-Cooper, H. (2008). Post-meiotic transcription in Drosophila testes. Development 135, 1897-1902. doi: 10.1242/dev.021949

Krysan, J. L. (1990). Laboratory study of mating-behavior as related to diapause in overwintering Cacopsylla-Pyricola (Homoptera, Psyllidae). Environ. Entomol. 19, 551-557. doi: 10.1093/ee/19.3.551

Krysan, J. L., and Higbee, B. S. (1990). Seasonality of mating and ovarian development in overwintering Cacopsylla-Pyricola (Homoptera, Psyllidae). Environ. Entomol. 19, 544-550. doi: 10.1093/ee/19.3.544

Maines, J. Z., and Wasserman, S. A. (1999). Post-transcriptional regulation of the meiotic Cdc25 protein Twine by the Dazl orthologue Boule. Nat. Cell Biol. 1, 171-174.

Sadakiyo, S., and Ishihara, M. (2012). Cost of male diapause indirectly affects female reproductive performance. Entomol. Exp. Appl. 143, 42-46. doi: 10.1111/j.1570-7458.2012.01223.x

Conflict of Interest Statement: The authors declare that the research was conducted in the absence of any commercial or financial relationships that could be construed as a potential conflict of interest.

Copyright (c) 2017 Kubrak, Kučerová, Theopold, Nylin and Nässel. This is an open-access article distributed under the terms of the Creative Commons Attribution License (CC BY). The use, distribution or reproduction in other forums is permitted, provided the original author(s) or licensor are credited and that the original publication in this journal is cited, in accordance with accepted academic practice. No use, distribution or reproduction is permitted which does not comply with these terms. 